\title{
ХРОНИКА ПОЛИТИЧЕСКОЙ НАУКИ
}

16 мая 2003 г. в Москве состоялся круглый стол “Три этапа реформ в России: перестройка, 90-е годы, современность”, организованный Академией политической науки. С основным докладом, посвященным анализу этапов российских реформ, выступил член президиума АПН проф. Ю.Красин. Содоклад "Российские СМИ - субъект и объект реформ: дивиденды от успехов и ответственность за неудачи" представил президент АПН проф. А. Чумиков, познакомивший участников круглого стола с результатами исследования "Становление СМИ как инструмента демократии: политика государства и частных корпораций”, проведенного Международным прессклубом.

На круглом столе выступили также проф. Е.Андрющенко, проф. М.Бочаров, проф. Г.Водолазов, проф. А.Воржецов (Казань), проф. А.Кириллов (Екатеринбург), проф. В.Кулинченко, проф. С.Рогачев, проф. В.Шевченко. В центре развернувшейся дискуссии, наряду с оценкой опыта российских реформ, оказался вопрос о роли политической науки в реформировании страны. Выступавшие обсуждали перспективы участия политологов в работе Общественной палаты при Президенте РФ, говорили о необходимости повышения гласности в деятельности АПН и более полном ее освещении в СМИ.

А. Чумиков

26-28 мая 2005 г. в Москве проходила международная конференция “Инновационные подходы к созданию системы безопасности и сотрудничества в Северо-Восточной Азии”, организованная РАПН совместно с Межрелигиозной межнациональной федерацией за мир во всем мире при содействии Центра политических и международных исследований, Федерации мира и согласия, Центра Евро-Атлантической безопасности МГИМО(У) МИД РФ, Института Дальнего Востока РАН и ряда других научных и общественных организаций.

Ученые и общественные деятели из России, США, Китая, Японии, Монголии и Республики Корея обсудили пути и способы нормализации ситуации на Корейском полуострове, указав на важность экономического, научно-технического и гуманитарного сотрудничества между двумя корейскими государствами, которое может и должно послужить прообразом многосторонних механизмов безопасности для субрегиона в целом. Особое внимание участники уделили перспективам реализации инфраструктурных проектов, включая создание единой энергетической и транспортной систем как основы последующей экономической и политической интеграции КНДР и РК. Поскольку успешное развитие такого рода проектов отвечает экономическим и политическим интересам России в Северо-Восточной Азии и АТР, активное и заинтересованное участие в дискуссии приняли представители МИД, МПС, РАО ЕЭС и ряда других министерств и ведомств РФ. 
30 мая 2005 г. в малом конференцзале ИНИОН РАН в рамках методологического семинара РАПН состоялась встреча с классиком современной социологии профессором И.Валлерстайном. Основной темой беседы была быстро меняющаяся геополитика современной миросистемы. По мнению проф. Валлерстайна, в настоящее время мы вступили в период трансформации, исход которой трудно предсказать, ибо он определяется развитием по крайней мере трех конфликтов: (1) между тремя главными центрами накопления капиталов (США, Западная Европа, Юго-Восточная Азия), первый из которых пребывает в фазе упадка, а два последних подъема; (2) между глобальным Севером и глобальным Югом; (3) между силами, являющимися проводниками глобализма, и антиглобалистами. Согласно оценке проф. Валлерстайна, миросистема находится сегодня в точке бифуркации и направление ее дальнейшей эволюции зависит от множества факторов, в т.ч. от усилий отдельных организаций и даже индивидов. В ходе выступления И.Валлерстайн коснулся вопроса и о месте России в указанных конфликтах, подчеркнув, что пока непонятно, является ли наша страна частью богатого Севера, и если так, то с каким из центров накопления капитала она готова вступить в союз, а если нет, то готова ли она осознать себя частью Юга.

На семинаре выступили также проф. А.Соловьев, проф. О.Гаман-Голутвина, проф. Л.Поляков и др.

О.Малинова

В мае-июне 2005 г. в Петрозаводске, Великом Новгороде и Пскове прошли семинары Исследовательского комитета по проблемам прав человека РАПН на тему “Права иеловека как предмет изучения и обучения”, в которых приняли участие преподаватели и студенты местных вузов, представители общественных организаций, гости из Москвы и Санкт-Петербурга. На семинарах обсуждались сложности, сопряженные с изучением прав человека, перспективы их преодоления, анализировался уже накопленный опыт. В рамках семинаров состоялась презентация вышедших под эгидой Исследовательского комитета книг "Права человека и проблемы идентичности в России и современном мире ” $($ СПб,2005) и “Общество и власть: пути взаимодействия" (СПб,2005).

На семинарах в Великом Новгороде и Пскове с докладом “Дискурс о правах человека в России - спорные вопросы и проблемы коммуникации "выступила д.филос.н. О.Малинова (ИНИОН РАН). Рассмотрев исторические этапы становления понятия прав человека и отдельные дискуссионные аспекты его современной трактовки, она обратила внимание присутствующих на те конкретные проблемы, которые возникают при практической реализации прав человека в современной российской действительности. Главная из них - отсутствие традиции диалога (в т.ч. научного) на данную тему, причем не только между обществом и государством, но и внутри самой общественности. Между тем, как подчеркнула докладчица, лишь постоянный диалог, творческий общественный дискурс может положить конец выстраиванию “безумной вертикали” власти в отрыве от общества. Узурпация понятия прав человека отдельной об- 
щественной группой или государственной властью - явление вредное и деструктивное. Права человека должны стать тем объединяющим фактором, который будет способствовать расширению "общественной коммуникации "и предотвращению социального распада.

А.Сунгуров, А.Лобачев

23 июня 2005 г. состоялось заседание Программного комитета Четвертого Всероссийского конгресса политологов . В заседании приняли участие С.Патрушев, С.Айвазова, О.Гаман-Голутвина, В.Коваленко, Ю.Красин, В.Сергеев. Материалы к заседанию были направлены Л.Сморгунову, Л.Фадеевой и М.Фарукшину.

На заседании были обобщены результаты первого тура дискуссии относительно основной темы Конгресса и принято решение вынести на обсуждение членов политологического сообщества России следующие варианты:

- Российская политика и политическое знание: сопротивление материала.

- Политическое развитие России: коридор возможностей.

- Управляемая демократия или демократическое правление: российская дилемма?

- Демократия, безопасность и эффективное управление: новые вызовы для политической науки.

Программный комитет уточнил перечень субдисциплинарных направлений, по которым будет предложено подавать индивидуальные заявки на следующем этапе подготовки Конгресса. В их число вошли: теория и методология политики; история политической мысли; политическая философия; политическая идеология; сравнительная политология; политические исследования зарубежных стран; политические исследования в зарубежных странах; принятие политических решений; гражданское общество; гражданская политика; социальная политика; публичная политика; политическая психология; политическая культура; политическая социология; политическое участие; политическая элитология; политическое лидерство; партология; электоральные исследования; политическая регионалистика; политическая конфликтология; политика и религия; гендерные политические исследования; политическая антропология; ретроспективная политология; политическая коммуникация; Интернет, политика, политология; политическая лингвистика; политическая семиотика; политическая информатика; мировая политика; геополитика; политическая глобалистика; политическая безопасность; политическая экономия; политическая география; этнополитология; военная политология; политическая этика; науковедение политологии; прикладная политология; преподавание политической науки; политическое и политологическое образование.

Второй тур электронной дискуссии относительно основной темы Конгресса будет проходить с 1 июля по 15 сентября с.г. Прием индивидуальных заявок на участие в Конгрессе начнется 1 октября. 